\title{
ORTHODONTIST CLINICAL EXPERIENCE AND CLINICAL SITUATION SIGNIFICANTLY INFLUENCE THE RETENTION PROTOCOL - A SURVEY FROM CROATIA
}

\begin{abstract}
Zoran Popović1 ${ }^{1}$ Magda Trinajstić Zrinski² and Stjepan Špalj²
${ }^{1}$ Private Dental Practice, Rijeka, Croatia;

${ }^{2}$ Department of Orthodontics, University of Rijeka Faculty of Dental Medicine, Rijeka, Croatia

SUMMARY - The aim was to assess the views and practice of Croatian orthodontists concerning retention protocols. A total of 150 questionnaire copies were distributed, of which 92 were validly completed. The survey included sociodemographic characteristics, practices of informing patients about retention options, commonly used appliances, and reasons for choosing a particular type of retention and treatment duration. Orthodontists informed patients about retention mostly verbally, the retention period was 3-5 years, the choice of method depended on the malocclusion (76\%), and the protocol was influenced by clinical experience of the orthodontist (39\%). The most commonly used appliance in the maxilla was the vacuum-formed retainer (52\%), whereas a combination of fixed and removable retainers was most common in the mandible (34\%). Modus of acquiring knowledge, biological reasons (malocclusion type, oral health, treatment outcome, and growth) and the patient's wishes were not a predictor of retention duration or recall frequency. With an increase in orthodontic experience, the duration of retention decreased and orthodontists were more likely to change the duration of retention ( $\mathrm{p}=0.001)$, as well as the type of retention appliance $(\mathrm{p}<0.001)$. In conclusion, retention protocols among Croatian orthodontists were influenced mostly by their clinical experience and clinical situation.
\end{abstract}

Key words: Croatia; Clinical protocols; Orthodontic appliances; Orthodontic retainers; Orthodontics, corrective - methods; Surveys and questionnaires

\section{Introduction}

Orthodontic therapy comprises two phases described as active treatment and retention. Retention protocols depend on the presenting malocclusion type, patient age, treatment duration and outcome, but also on the clinician's education and clinical experience. For decades, the retention phase has been the most controversial phase of clinical orthodontics as there are no precise or widely accepted rules on the type, modus and duration. Due to the etiologic uncertainty of a malocclusion, an individual approach to patients is of-

Correspondence to: Magda Trinajstić Zrinski, DMD, PhD, Krešimirova 40, HR-51000 Rijeka, Croatia

E-mail: magda.zrinski@fdmri.uniri.hr

Received December 1, 2014, accepted June 6, 2016 ten necessary ${ }^{1}$. Neuromuscular balance, elasticity of the gingiva and periodontal ligament, occlusion stability, therapeutic factors and growth are known factors that affect relapse of a treated malocclusion ${ }^{2}$.

Depending on the anomaly, there is a reported pattern and frequency of relapse. Rotated teeth are very susceptible to relapse post-treatment change and, surprisingly, their movement does not depend on available space. Even in extraction treatment, tooth rotational relapse can occur. In cases of class II sagittal relationship correction, an increase in overjet may occur, whereas in class III cases, late mandibular growth may cause reappearance of a mesio-occlusion.

During the finishing phase of orthodontic treatment, overcorrection of the malocclusion and circumferential supracrestal fiberotomy are the mechanisms 
Table 1. Content of the questionnaire, outcome variables and predictors

\begin{tabular}{|c|c|c|}
\hline Questionnaire content & Variable & $\begin{array}{l}\text { Predictor } \\
\text { / outcome }\end{array}$ \\
\hline $\begin{array}{l}\text { Orthodontist } \\
\text { sociodemographic } \\
\text { characteristics }\end{array}$ & $\begin{array}{l}\text { Age } \\
\text { Gender } \\
\text { Place of residency program }\end{array}$ & Predictor \\
\hline Clinical experience & $\begin{array}{l}\text { Years of clinical experience } \\
\text { Weekly days of work with patients }\end{array}$ & Predictor \\
\hline $\begin{array}{l}\text { Modus of acquiring } \\
\text { knowledge of retention }\end{array}$ & $\begin{array}{l}\text { Residency, literature, courses, discussion with colleagues, clinical } \\
\text { experience }\end{array}$ & Predictor \\
\hline $\begin{array}{l}\text { Arguments for choice } \\
\text { and duration of retention }\end{array}$ & $\begin{array}{l}\text { Tooth morphology, malocclusion type, treatment outcome, } \\
\text { oral health and hygiene, patient wishes and motivation, } \\
\text { craniofacial growth, eruption of wisdom teeth }\end{array}$ & Predictor \\
\hline Clinical situation & $\begin{array}{l}\text { Open bite, spacing, rotated teeth, impacted canines, frontal expansion, } \\
\text { lateral expansion, extraction }\end{array}$ & Predictor \\
\hline Retention protocol & $\begin{array}{l}\text { Appliance type: acrylic plate, vacuum formed retainer, bonded retainer } \\
\text { 2-2, bonded 3-3, activator, positioner, headgear } \\
\text { Duration of retention: in first year, after first year } \\
\text { Frequency of recalls } \\
\text { Changes in protocols in the last } 5 \text { years }\end{array}$ & Outcome \\
\hline $\begin{array}{l}\text { Informing patient on } \\
\text { retention }\end{array}$ & $\begin{array}{l}\text { Mode of informing patient: verbal, written, both, none } \\
\text { Information content: duration, type, hygiene, complications } \\
\text { Time of informing the patient: at the start of orthodontic treatment, } \\
\text { at the end }\end{array}$ & Outcome \\
\hline $\begin{array}{l}\text { Retention appliance } \\
\text { production and placement }\end{array}$ & Technician, orthodontist, dental assistant & Outcome \\
\hline $\begin{array}{l}\text { Personnel that follow up } \\
\text { patients after } 2^{\text {nd }} \text { year }\end{array}$ & Orthodontist, his general dentist, himself & Outcome \\
\hline $\begin{array}{l}\text { Views about need for } \\
\text { guidelines for retention } \\
\text { treatment }\end{array}$ & Guidelines needed, not needed, not sure & Outcome \\
\hline
\end{tabular}

that have been used to limit relapse. Modifications of Schwarz plate are the most common removable appliances used for retention, whereas fixed bonded retainers are usually used in combination with removable vacuum-formed appliances.

The aim of the present survey was to assess the views and clinical practice of Croatian orthodontists concerning their retention protocol. In addition, the characteristics of the orthodontist including sociodemographic characteristics, clinical experience and sources of knowledge, and patient features describing biological and occlusal characteristics, wishes and motivation were investigated to determine predictive differences in retention protocols.

\section{Materials and Methods}

In this cross-sectional research, 150 questionnaire copies were distributed by e-mail at an orthodontic course or individually over a period of 12 months (April 2012 until April 2013). Ninety-two questionnaires were appropriately filled out and returned (response rate $61.3 \%$ ), which represented $42 \%$ of the total number of orthodontists in Croatia. The questionnaire contained 14 questions with the possibility of a single or multiple answer choice. The content of the questionnaire is shown in Table 1.

The $\chi^{2}$-test, Fisher exact test, Mann-Whitney test, and Spearman and point-biserial correlations were 
Table 2. Most commonly used retention appliance according to type of malocclusion (prevalence $(P) n(\%)$ and years of clinical experience (E) of orthodontists (median (interquartile range))

\begin{tabular}{|c|c|c|c|c|c|c|}
\hline & \multicolumn{3}{|c|}{ Maxilla } & \multicolumn{3}{|c|}{ Mandible } \\
\hline & Bonded & Removable & Combination & Bonded & Removable & Combination \\
\hline Extraction & $\begin{array}{l}\text { P } 8(8.7 \%)^{\mathrm{a}} \\
\text { E 2.5 (0.25-8.5) }\end{array}$ & $\begin{array}{l}33(35.9 \%)^{\mathrm{b}} \\
9(3-19.5)\end{array}$ & $\begin{array}{l}51(55.4 \%)^{\mathrm{b}} \\
7(3-14)\end{array}$ & $\begin{array}{l}17(18.5 \%)^{\mathrm{a}} \\
9(4.5-17.5)\end{array}$ & $\begin{array}{l}30(32.6 \%)^{\mathrm{ab}} \\
4.5(0.75-21)\end{array}$ & $\begin{array}{l}45(48.9 \%)^{\mathrm{b}} \\
7(3-10.5)\end{array}$ \\
\hline Spacing & $\begin{array}{l}\text { P } 23(25 \%)^{a} \\
\text { E } 8(1-19)\end{array}$ & $\begin{array}{l}25(27.2 \%)^{\mathrm{ab}} \\
9(1-21)\end{array}$ & $\begin{array}{l}44(47.8 \%)^{\mathrm{b}} \\
5(4-11.5)\end{array}$ & $\begin{array}{l}32(34.8 \%)^{\mathrm{ab}} \\
8.5(4-19)\end{array}$ & $\begin{array}{l}20(21.7 \%)^{a} \\
7(0.25-23.75)\end{array}$ & $\begin{array}{l}40(43.5 \%)^{\mathrm{b}} \\
5(3.25-9)\end{array}$ \\
\hline $\begin{array}{l}\text { Frontal } \\
\text { expansion }\end{array}$ & $\begin{array}{l}\text { P } 5(5.4 \%)^{a} \\
\text { E } 9(5-14)\end{array}$ & \begin{tabular}{|l}
$54(58.7 \%)^{\mathrm{b}}$ \\
$7.5(1-17.25)$
\end{tabular} & $\begin{array}{l}33(35.9 \%)^{\mathrm{b}} \\
7(4-16.5)\end{array}$ & $\begin{array}{l}16(17.4 \%)^{\mathrm{a}} \\
10.5(5.5-18.25)\end{array}$ & $\begin{array}{l}40(43.5 \%)^{\mathrm{b}} \\
7.5(1.25-17)\end{array}$ & $\begin{array}{l}36(39.1 \%)^{\mathrm{b}} \\
4.5(3-9.75)\end{array}$ \\
\hline $\begin{array}{l}\text { Lateral } \\
\text { expansion }\end{array}$ & $\begin{array}{l}\text { P } 1(1.1 \%)^{a} \\
\text { E } 1\end{array}$ & $\begin{array}{l}60(65.2 \%)^{\mathrm{b}} \\
6.5(1-15.5)\end{array}$ & $\begin{array}{l}31(33.7 \%)^{c} \\
7(4-13)\end{array}$ & $\begin{array}{l}8(8.7 \%)^{\mathrm{a}} \\
11.5(7.25-18.25)\end{array}$ & $\begin{array}{l}55(59.8 \%)^{\mathrm{b}} \\
5(1-17)\end{array}$ & $\begin{array}{l}29(31.5 \%)^{c} \\
7(3.5-13)\end{array}$ \\
\hline $\begin{array}{l}\text { Impacted } \\
\text { canines }\end{array}$ & $\begin{array}{l}\text { P } 15(16.3 \%)^{a} \\
\text { E } 9(2-20)\end{array}$ & $\begin{array}{l}44(47.8 \%)^{\mathrm{b}} \\
7(1-15.5)\end{array}$ & $\begin{array}{l}33(35.9 \%)^{\mathrm{b}} \\
7(4-13)\end{array}$ & $\begin{array}{l}24(26.1 \%) \\
8.5(5.5-19)\end{array}$ & $\begin{array}{l}41(44.6 \%) \\
5(1-18.5)\end{array}$ & $\begin{array}{l}27(29.3 \%) \\
5(3-9)\end{array}$ \\
\hline $\begin{array}{l}\text { Rotated } \\
\text { teeth }\end{array}$ & $\begin{array}{l}\text { P } 20(21.7 \%)^{\mathrm{a}} \\
\text { E } 9.5(1-19.75)^{\mathrm{ab}}\end{array}$ & $\begin{array}{l}19(20.7 \%)^{\mathrm{a}} \\
14(5-26)^{\mathrm{b}}\end{array}$ & $\begin{array}{l}53(57.6 \%)^{\mathrm{b}} \\
5(3-9.5)^{\mathrm{a}}\end{array}$ & $\begin{array}{l}31(33.7 \%)^{\mathrm{ab}} \\
8(2-19)^{\mathrm{ab}}\end{array}$ & $\begin{array}{l}15(16.3 \%)^{\mathrm{a}} \\
19(4-27)^{\mathrm{b}}\end{array}$ & $\begin{array}{l}46(50 \%)^{\mathrm{b}} \\
2.75(4-9)^{\mathrm{a}}\end{array}$ \\
\hline Open bite & $\begin{array}{l}\text { P } 18(19.6 \%)^{a} \\
\text { E } 8.5(4-17.5)\end{array}$ & $\begin{array}{l}31(33.7 \%)^{\mathrm{ab}} \\
9(1-23)\end{array}$ & $\begin{array}{l}43(46.7 \%)^{\mathrm{b}} \\
5(3-12)\end{array}$ & $\begin{array}{l}27(29.3 \%) \\
9(5-19)\end{array}$ & \begin{tabular}{|l|}
$23(25 \%)$ \\
$3(1-24)$ \\
\end{tabular} & $\begin{array}{l}42(45.7 \%) \\
6(3-12.5)\end{array}$ \\
\hline
\end{tabular}

*values that share the same superscript letters in each jaw do not differ significantly at $\mathrm{p}<0.05$ according to $\chi^{2}$-test for prevalence $(\mathrm{P})$ and Kruskal-Wallis and Mann-Whitney test with Bonferroni correction for years of clinical experience (E).

used on statistical analysis, which was performed using SPSS 10.0 software (SPSS, Chicago, USA).

\section{Results}

The analyses were conducted on the returned sample of 92 actively practicing orthodontic specialists (female $76.1 \%$ ) aged $27-75$ years (median 39 , inter-quartile range (IQR) 34-54). The orthodontists practiced and treated patients mainly for 5 days per week. Most had attended an orthodontic program in the Croatian capital of Zagreb (87\%), whereas others had acquired qualifications in neighboring Eastern European countries of Bosnia and Herzegovina, Serbia, Slovenia, Macedonia and Russia. Differences in age, years of work experience, weekly work with patients and city of residency were not statistically significant between the genders.

The majority of orthodontists informed their patients about retention at the beginning of orthodontic treatment $(95 \%)$, mostly verbally $(65 \%)$ or verbally and in writing (29\%), and the information delivered included retention type (58\%) and duration (59\%). At the beginning of the retention period, $60 \%$ of the orthodontists provided information only verbally and $35 \%$ verbally and in writing, which included informa-

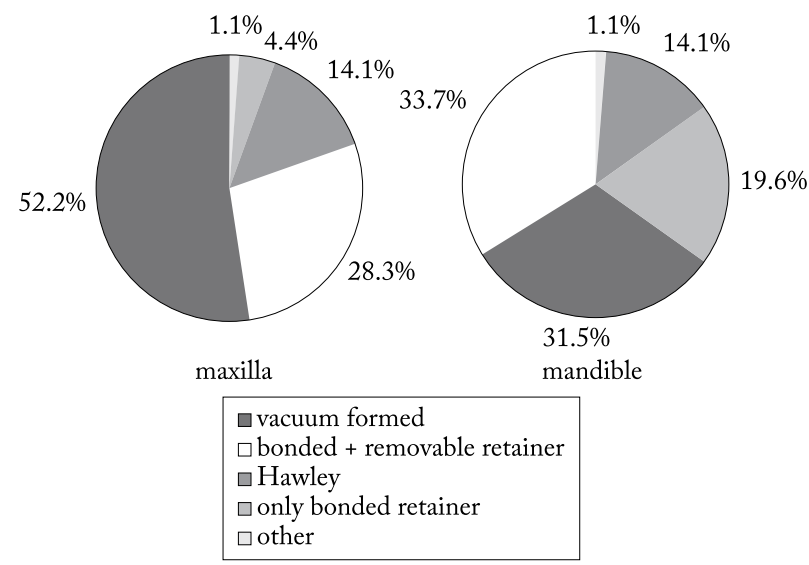

Fig. 1. Most commonly used retainers.

tion on the risks and problems (73\%), use of interdental brush (49\%), dental floss (33\%), toothpick (15\%) and electric toothbrush (16\%).

The median retention period was 3-5 years (equally in both jaws), which consisted of a median of four appointments in the first year (equally with both fixed and removable retainers) and three appointments thereafter. In $17 \%$ of cases, patients were entrusted to monitor the potential change themselves after the third year of retention.

The vacuum-formed appliance was most often used in the maxilla, whereas a combination of fixed 
Table 3. Treatment related reasons for choice of retention protocol

\begin{tabular}{|l|l|l|}
\hline $\begin{array}{l}\text { Reason for choice of retention } \\
\text { protocol }\end{array}$ & Prevalence & $\begin{array}{l}\text { Years of clinical experience } \\
\text { (median and interquartile range) }\end{array}$ \\
\hline Malocclusion & $70(76.1 \%)$ & $6(2-14)$ \\
Treatment result & $54(58.7 \%)$ & $7(3-17)$ \\
Oral hygiene & $31(33.7 \%)$ & $9(4-18)$ \\
Periodontal health & $25(27.2 \%)$ & $7(4-12)$ \\
Patient wishes and motivation & $40(43.5 \%)$ & $5(1-14)$ \\
Patient age/completion of growth & $37(40.2 \%)$ & $5(4-12)$ \\
Myofunctional state & $28(30.4 \%)$ & $5(3-16.5)$ \\
Tooth morphology & $4(4.3 \%)$ & $4.5(3-6)$ \\
Wisdom teeth & $14(15.2 \%)$ & $11.5(4-20)$ \\
\hline
\end{tabular}

Table 4. Changes in retention protocol

\begin{tabular}{|l|l|l|}
\hline $\begin{array}{l}\text { Change of protocol in the last } \\
5 \text { years }\end{array}$ & Prevalence & $\begin{array}{l}\text { Years of clinical experience } \\
\text { (median and interquartile range) }\end{array}$ \\
\hline $\begin{array}{l}\text { No change } \\
\text { Change in the type of retention } \\
\text { appliance }\end{array}$ & $50(54.3 \%)$ & $4(1-12.5)$ \\
$\begin{array}{l}\text { Change in the period of wearing } \\
\text { the retention appliance }\end{array}$ & $25(27.2 \%)$ & $16(7-23)$ \\
\hline
\end{tabular}

and removable appliances was most common in the mandible (Fig. 1). Retention appliances employed in different clinical situations are shown in Table 2, the principal reasons for choosing a retention protocol in Table 3 , and the prevalence of changes in the retention protocol in Table 4. The selection of protocol was mostly influenced by clinical experience of the orthodontist (39\%), their acquired knowledge from their education programs (26\%), and the knowledge gained from courses (21\%). Removable appliances were mostly made at a laboratory (83\%), whereas bonded appliances were made and placed by the orthodontist (96\%). Eighty-six percent of orthodontists would like to have general guidelines for the retention phase.

There were no significant differences in the duration of retention and frequency of recalls between the types of appliances used generally, or according to clinical situations. The orthodontist's age and years of experience were associated with the duration of retention. An increase in the orthodontist's age was related to a shorter retention period; however, the correlation was weak $(r=-0.278 ; p=0.007$ for maxilla and $r=-0.279$; $\mathrm{p}=0.007$ for mandible). The years of orthodontic experience was a weaker predictor of retention duration
( $\mathrm{r}=-0.266$ and $\mathrm{r}=-0.250$ for maxilla and mandible, respectively).

With an increase in age and orthodontic experience, orthodontists were more likely to report that they had changed their retention duration in the past five years $(r=-0.285 ; p=0.006$ and $r=-0.337 ; p=0.001$ ), as well as the type of retention appliance used $(\mathrm{r}=0.352$; $\mathrm{p}=0.001$ and $\mathrm{r}=0.405 ; \mathrm{p}<0.001)$. Older orthodontists and those with longer clinical experience less often reported choosing retention on the basis of knowledge gained during residency $(\mathrm{r}=-0.274 ; \mathrm{p}=0.008$ and $\mathrm{r}=-$ $0.378 ; \mathrm{p}<0.001)$ and more often based on their experience $(r=0.323 ; p=0.002)$.

The manner of acquiring knowledge of retention, the biological reasons (malocclusion type, oral health, treatment outcome, and growth) and the patient's wishes were not predictors of the duration of retention or the frequency of recalls. The acrylic plate-type retainer was more often used by more experienced orthodontists (median years of experience 24 (IQR 9.528)) than the vacuum-formed retainer (median years of experience 4 (IQR 1-12); $\mathrm{p}=0.001$ ). In a particular clinical situation, experience was a significant predictor of appliance choice but only in cases of rotated 
teeth in which removable appliances were used in both jaws by more experienced orthodontists, whereas those less experienced used a combination of removable and bonded retainers (Table 2).

Male practitioners were more likely to provide written information to patients at the beginning of the retention phase $(\mathrm{r}=0.262 ; \mathrm{p}=0.012)$. Males placed fixed retention after extractions in the mandible $(\mathrm{r}=0.324$; $\mathrm{p}=0.002$ ), conducted fewer recalls after the first year of retention $(r=-0.284 ; \mathrm{p}=0.006)$ and less often provided periodontal health as a reason for the choice of retainer $(r=-0.285 ; p=0.006)$.

Orthodontists who changed the choice of retention appliance used a vacuum-formed retainer less often in the mandible $(\mathrm{r}=-0.257 ; \mathrm{p}=0.014)$ and used a bonded retainer more often in cases of impacted canines in the maxilla $(r=0.326 ; p=0.002)$. The duration of retention was not associated with the information provided to the patient regarding retention. Information about the duration of retention was related to wisdom teeth as a reason for choosing retention appliance $(r=0.294 ; p=0.004)$.

\section{Discussion}

Clinical experience and a particular clinical situation appear to be the most significant factors affecting retention protocol among Croatian orthodontists. The increasing years of experience were associated with the use of the acrylic plate-type retainers in both arches, and less often vacuum-formed retainers. A likely cause of this practice is the late introduction of vacuumformed retainers in clinical practice in Croatia. In contrast, experienced orthodontists in Norway more often use a fixed retainer bonded to the six anterior teeth ${ }^{3}$. The current research has shown that Croatian orthodontists most commonly use vacuum-formed retentive appliances in the upper arch (52\%) and a combination of bonded and removable appliances in the lower arch (34\%). These results indicate that orthodontists are aware of the frequency of relapse and the importance of retention in the mandibular intercanine region. Previous research in the USA demonstrated that the appliance most often used in the maxilla was the Hawley retainer, followed by vacuum-formed appliances, and in a small percentage of cases a bonded retainer was used. In the mandible, the most commonly used retainers were bonded canine-to-canine retainer, a Haw- ley retainer and, finally, a vacuum-formed retainer, often made in a dental laboratory ${ }^{4}$. The most commonly used appliances in Australia and New Zealand are the vacuum formed retainer in the upper arch and bonded canine-to-canine retainer in the lower arch, with a preferred 0.0175 inch twisted steel wire ${ }^{5}$. In the maxilla, Norwegian orthodontists most commonly use a combination of fixed and removable appliances, a vacuum-formed retainer, and finally a Hawley retainer, and a fixed retainer bonded to the six anterior teeth in the mandible ${ }^{3}$. There is a global trend among orthodontists to prefer a removable retainer in the maxilla and a bonded retainer or a combination of fixed and removable retention in the mandible. This retention protocol was not different between genders among Croatian orthodontists, whereas in Norway female orthodontists usually use a combination of fixed and removable retention in the upper arch. Male orthodontists preferred vacuum-formed retainers ${ }^{3}$. A study in the Netherlands showed that a high percentage of orthodontists had changed retention management in the last 5 years ${ }^{6}$. During the same period, US orthodontists also changed their preferred type of retention appliance. Although the Hawley retainer was still the most commonly used in the maxilla, $44 \%$ of orthodontists reduced its use, and $29 \%$ of them were planning to increase the use of the vacuum-formed retainer ${ }^{7}$. A possible explanation for this is that patients preferred the aesthetics of the clear vacuum-formed retainer over Hawley retainer, while orthodontists may favor the simplicity and speed of its manufacture.

It appears that vacuum-formed retainer is more effective than Hawley retainer in preventing relapse in the mandible. Another disadvantage of the Hawley appliance is its point contact with labial surfaces of frontal teeth, whereas the vacuum formed retainer covers whole tooth crowns ${ }^{8}$. The bonded retainer is effective in the mandibular intercanine sector, but in a significant percentage of patients, there is still a small to moderate increase in the irregularity index. The cause of this change is usually detachment of the wire of which the patient was unaware and did not immediately report ${ }^{8}$.

The present study showed that more experienced orthodontists more often changed their retention protocol related to the type of retention appliance, and rarely determined retention based on knowledge gained during training. A decision regarding retention 
was based on clinical experience, which confirms the result of a Norwegian study ${ }^{3}$. This is logical and expected because over time, there is new evidence-based knowledge and therapists themselves learn from their own mistakes.

The duration of retention is being reduced with orthodontist increase in age and clinical experience. Several studies have presented differing results, such as an increase in recalls during retention with an increase of orthodontic experience ${ }^{10}$. If the orthodontist decided to use a vacuum-formed retainer, recalls were less frequent ${ }^{10}$. If the duration of retention was determined to be 12 months, four recalls per year were arranged, and in cases in which retention was set for over 1 year, recalls were appointed every 6 months ${ }^{10}$. A higher incidence of relapse within the first year of retention makes quarterly recalls during the first year a sensible choice. Alternatively, reduction of recall frequency in retention duration set to be over 1 year is probably reflection of the desire to increase the cost-efficiency of managing an orthodontic practice, since minimizing overheads and a high number of active cases are characteristics of a successful practice ${ }^{11}$.

Studies conducted among orthodontists in the UK reveal that the most common retention period is 12 months ${ }^{12}$. This approach was corroborated by histologic studies that have shown that supracrestal periodontal fibers remain stretched and distorted for more than 7 months after cessation of active treatment, suggesting that retention therapy should last for at least 7 months ${ }^{13,14}$.

Some clinicians extend the retention phase because of fear of relapse, whereas others decide it should last for life. During the retention phase, the patient's wishes and expectations should be taken into account because if he/she would not tolerate any relapse at all, it is necessary to consider permanent fixed or removable retention ${ }^{15}$. This may be one reason why, in recent times, orthodontists have often opted for permanent retention.

Many reasons influence the selection of a particular type of retainer. The main reason for Croatian orthodontists is the presenting malocclusion, just as in Australia and New Zealand ${ }^{5}$, Norway ${ }^{3}$ and the Netherlands ${ }^{6}$. Removable retention appliances are mostly used by Croatian orthodontists in cases of frontal and lateral expansion and impacted canines, and a combination of fixed and removable retainer in cases charac- terized by extraction, spacing, rotation or open bite. Similarly, in the Netherlands, most orthodontists use a permanently bonded retainer in the maxilla and mandible, except for the cases of upper dental arch expansion with or without extraction, when removable appliances are used instead ${ }^{6}$. Other reasons for choosing a retention regimen include intercuspation after therapy, the patient's oral hygiene, treatment result, periodontal health, and the patient's wishes and motivation $^{6}$. Wisdom teeth are the reason for selecting the type of retention appliance in a very small percentage, but in the present study they were found to be significantly associated with informing patients about the duration of retention therapy. The reason for this could be the fact that the retention phase of treatment often begins before the eruption of wisdom teeth or an obsolete theory that the eruption of wisdom teeth causes late anterior crowding.

Although this study provided an insight into the retention protocols of Croatian orthodontists, clinicians all over the world face the same issues regarding the long-term stability of orthodontic treatment results and use similar appliances in retention. The results of the current research may prove useful in informing the clinician about various aspects of retention and changes in clinical practice related to experience.

There are different viewpoints related to the need for general guidelines in retention therapy that would help determine orthodontic treatment. In Norway, $50 \%$ of orthodontists deem that it would be helpful if guidelines existed ${ }^{3}$, while in the Netherlands this percentage is slightly higher $(59 \%)^{9}$. In Croatia, $86 \%$ of the orthodontists want general guidelines and believe these would be useful.

It should be noted that the present survey might suffer from a bias related to the clinicians' memory, which may be selective. However, this recall bias is a common problem present in retrospective and questionnaire survey designs.

\section{Conclusions}

The most commonly used retention appliance in Croatia is the vacuum-formed retainer in the maxilla and a combination of fixed and removable appliances in the mandible. Retention protocols among Croatian orthodontists are influenced by the clinical situation and their clinical experience. 


\section{Acknowledgment}

The research was financed by the University of $\mathrm{Ri}-$ jeka as part of the research project 13.06.2.1.53; principal investigator Stjepan Špalj.

\section{References}

1. Littlewood SJ, Millet DT, Doubleday B, Bearn DR, Worthington HV. Orthodontic retention: a systematic review. J Orthod. 2006;33:205-12. DOI: 10.1179/146531205225021624

2. López-Areal L, Gandía JL. Relapse of incisor crowding: a visit to the Prince of Salina. Med Oral Patol Oral Cir Bucal. 2013;18:e356-61. DOI: 10.4317/medoral.18514

3. Vandevska-Radunovic V, Espeland L, Stenvik A. Retention: type, duration and need for common guidelines. A survey of Norwegian orthodontists. Orthodontics (Chic.) 2013;14: 110-7. DOI: $10.11607 /$ ortho. 964

4. Valiathana M, Hughes E. Results of a survey-based study to identify common retention practices in the United States. Am J Orthod Dentofacial Orthop. 2010;137:170-7. DOI: 10.1016 /j.ajodo.2008.03.023

5. Wong PM, Freer TJ. A comprehensive survey of retention procedures in Australia and New Zealand. Aust Orthod J. 2004; 20:99-106.

6. Renkema AM, Sips ETH, Bronkhorst E, Kuijpers-Jagtman AM. A survey on orthodontic retention procedures in the Netherlands. Eur J Orthod.2009;31:432-7. DOI: 10.1093/ejo/ cjn131
7. Pratt MC, Kluemper GT, Hartsfield JK Jr, Fardo D, Nash DA. Evaluation of retention protocols among members of the American Association of Orthodontists in the United States. Am J Orthod Dentofacial Orthop. 2011;140:520-6. DOI: 10.1016/j.ajodo.2010.10.023

8. Demir A, Babacan H, Nalcac R, Topcuoglu T. Comparison of retention characteristics of Essix and Hawley retainers. Korean J Orthod. 2012;42:255-62. DOI: 10.4041/kjod.2012.42.5.255

9. Renkema AM, Al-Assad S, Bronkhorst E, Weindel S, Katsaros C, Lissonf JA. Effectiveness of lingual retainers bonded to the canines in preventing mandibular incisor relapse. Am J Orthod Dentofacial Orthop. 2008;134:179e1-8. DOI: 10.1016/j.ajodo.2008.06.003

10. Bibona K, Shroff B, Best MA, Lindauerd SJ. Factors affecting orthodontists' management of the retention phase. Angle Orthod. 2014;84:225-30. DOI: 10.2319/051313-372.1.

11. Gottlieb EL, Nelson AH, Vogels DS III. 2001 JCO orthodontic practice study. Part 2: Practice success. J Clin Orthod. 2001;35:673-81.

12. Clark JD, Kerr WJ, Davis MH. Cases-clinical audit; scenarios for evaluation and study. Br Dent J. 1997;183:108-11. DOI: 10.1038/sj.bdj.4809434

13. Reitan K. Clinical and histologic observations on tooth movement during and after orthodontic treatment. Am J Orthod. 1967;53:721-45. DOI: 10.1016/0002-9416(67)90118-2

14. Edwards JG. A study of the periodontium during orthodontic rotation of teeth. Am J Orthod. 1968;54:441-61. DOI: 10.1016/0002-9416(68)90199-1

15. Johnston C, Burden D, Morris D. Clinical guidelines: orthodontic retention. The Royal College of Surgeons of England, 2008;1-9.

Sažetak

\section{KLINIČKO ISKUSTVO ORTODONTA I KLINIČKA SITUACIJA ZNAČAJNO UTJEČU NA RETENCIJSKI PROTOKOL}

\section{Z. Popovic, M. Trinajstic Zrinski i S. Špalj}

Cilj istraživanja bio je procijeniti stavove i praksu hrvatskih ortodonta u vezi s retencijskim protokolima. Distribuirano je ukupno 150 upitnika, od kojih su 92 valjano ispunjena. Pitanja su uključivala sociodemografske karakteristike, praksu informiranja pacijenta o mogućnostima retencije, najčěšce korištene naprave i razloge korištenja određenog protokola te trajanje retencije. Ortodonti su pacijente informirali o mogućnostima retencije najčešće usmeno, retencijsko razdoblje je bilo 3-5 godina, izbor metode ovisio je o malokluziji (76\%) te je na protokol utjecalo kliničko iskustvo ortodonta (39\%). Najčešće korištena naprava u maksili bila je termoplastična retencijska naprava (52\%), a u mandibuli kombinacija fiksne i mobilne retencijske naprave (34\%). Način usvajanja znanja, biološki razlozi (vrsta malokluzije, oralno zdravlje, terapijski ishod i rast) i pacijentove želje nisu bili prediktori trajanja retencije niti učestalosti kontrolnih pregleda. Porastom ortodontskog iskustva trajanje retencije smanjilo se te su ortodonti bili skloniji promijeniti trajanje retencije ( $\mathrm{p}=0,001)$, kao i vrstu retencijske naprave $(p<0,001)$. Zaključno, na retencijske protokole $u$ hrvatskih ortodonta najviše je utjecalo njihovo kliničko iskustvo $i$ klinička situacija.

Ključne riječi: Hrvatska; Klinički protokoli; Ortodontske naprave; Ortodontski retainer; Ortodoncija, korektivna - metode; Ankete i upitnici 